\title{
Smooth leaf (spineless) Red Spanish pineapple (Ananas comosus) propagated in vitro',
}

\author{
Lii J. Liu, Evelyn Rosa-Márquez and Enid Lizardis
}

\begin{abstract}
Some 40,000 plantlets of Red Spanish pineapple [Ananas comosus (L. Merr.)] were produced via meristem culture. Of these, approximately $50 \%$ were spineless. Some of these spineless plantlets reversed to spiny leaf. However, the percentage of reversion from spineless to spiny was $14.1 \%$ and that from spiny to spineless was $32.7 \%$. Of the 2,318 plantlets examined in the laboratory and greenhouse during a 3- to 4-month period, $72.9 \%$ of the spiny Red Spanish pineapple remained spiny and $85.8 \%$ of the spineless remained spineless. One year after field planfing, the spineless Red Spanish remained largely spineless and initiated flowering and fruit settings the same as the spiny ones. The standard medium for in vitro propagation of Red Spanish pineapple was improved by supplementing Murashige and Skoog's basic formula (MS) with $0.1 \mathrm{mg} / \mathrm{L}, 2,4$ dichlorophenoxyacetic acid $(2,4-D)+0.5 \mathrm{mg} / \mathrm{l}$ benzyl adenine (BA). The callus formation was improved by adding to the same MS formula $10 \mathrm{mg} / \mathrm{L}$ BA $+4 \mathrm{mg} / \mathrm{L}$ naphtalene acetic acid (NAA). Similarly, shoot differentiation was improved by adding low concentrations of hormone $(0.1 \mathrm{mg} / \mathrm{L}$ NAA) to the Abo El-Nil and Zettler (AZ) medium.
\end{abstract}

\section{RESUMEN}

Piña Española Roja sin espinas propagada in vitro

Se produjeron alrededor de 40,000 plántulas de piña [Ananas comosus (L. Merr.)] de la variedad Española Roja por cultivo de tejidos. Aproximadamente el $50 \%$ eran sin espinas. Algunas de las plántulas sin espinas revirtieron a plántulas con espinas. Sin embargo, el porcentaje de reversión de plántulas sin espinas a con espinas fue de $14.1 \%$ y de las con espinas a sin espinas de $32.7 \%$. Se observaron alrededor de 2,318 plántulas en el laboratorio y el invernadero por 3 a 4 meses. De éstas, el $72.9 \%$ de las con espinas las mantenían; $85.8 \%$ de los $\sin$ espinas permaneclan así. Después de un año de establecidas en el campo, la mayoría de las plantas sin espinas mantenían la característica y habían iniciado la floración para el mismo períado de tiempo que las con espinas. El medio de cultivo para propagar la Española Roja, in vitro se mejoró suplementándo la fórmula básica de Murashige \& Skoog (MS) con $0.1 \mathrm{mg} / \mathrm{L} \mathrm{2,} \mathrm{4-} \mathrm{diclorofonoxiacético}$ (2,4-D) + $0.5 \mathrm{mg} / \mathrm{L}$ benziladenina (BA). Se obtuvo la formación de callo

'Manuscript submitted to Editorial Board 17 March 1979.

2Supported in part, by USDA Cooperative State Research Service Grant No. 86-GRSR2-2813.

3Plant Pathologist and Research Assistants, Agricultural Experiment Station, University of Puerto Rico, Mayagüez Campus, Río Piedras, P.R. 00928. 
añadiendo $10 \mathrm{mg} / \mathrm{L}$ BA $+4 \mathrm{mg} / \mathrm{L}$ de ácido naftalinoacético (NAA) a la fórmula básica de MS y la diferenciación de los brotes añadiendo bajas concentraciones de hormonas (0.1 mg/L NAA) al medio de Abo EI Nil (AZ).

\section{INTRODUCTION}

Pineapple, Ananas comosus (L. Merr.), is economically the most important member of the Bromeliaceae and a major fruit crop in Puerto Rico as well as in the Caribbean Basin. The local farm value of this crop surpassed $\$ 13.24$ million in 1986 (2). The Land Authority of the Commonwealth of Puerto Rico is the largest pineapple producer on the island. In 1986, efforts were made by the Authority to increase pineapple production in the Isabela area for fresh fruit exportation to the United States. Recently, Costa Rica has initiated a program of producing 12,000 ha of good quality fresh pineapple for export. Similarly, the Dominican Republic has initiated a 5,000-ha fresh fruit pineapple production program. With the low wages in these two countries, Puerto Rico would have to rely upon its highly intensive, technically oriented production program for survival.

The major problem for pineapple production in Puerto Rico is its low yield per unit area. Whereas the average pineapple production in the world remains at 90 metric tons per hectare, Puerto Rico produces only 39.8 metric tons per hectare. Of the three major pineapple cultivars planted locally, Smooth Cayenne is spineless, but does not satisfy the tastes of consumers. Red Spanish satisfies the tastes of consumers and occupies more than $90 \%$ of the total pineapple growing area. The sharp spines on the leaves of the cultivar Red Spanish are a serious problem during cultural operations such as weeding, fertilizer application and flower induction and a potential limiting factor for commercial production. Smooth leaf mutants of pineapple were occasionally observed in fields in Puerto Rico as well as in Hawaii (4) and Venezuela $(7,14)$. However, these natural mutants gradually reversed to spiny and faded out from the plantation. Thus, it is extremely difficult to mass a huge number of smooth leaf mutants from the spiny Red Spanish pineapple for commercial production through the conventional sucker propagation techniques. Tissue culture techniques $(3,5,8,9,12,13)$ offer an alternative to the conventional propagation method. The present study was undertaken to determine the effect of hormone on callus formation, shoot differentiation, and proliferation; the possibility of selecting smooth leaf pineapple plants in-vitro and the frequency of reversion from spiny to smooth leaf among plants of a normally spiny cultivar.

\section{MATERIALS AND METHODS}

The smooth leaf mutant reversions from the spiny Red Spanish cultivar were obtained from the Land Authority in Barceloneta, Manatí. Lateral buds ( 0.4 to $0.8 \mathrm{~mm}$ ) and meristem tips from the crown of the 
pineapple fruits were removed, and surface was sterilized in Clorox $10 \%$ and Tween 80 (2 drops $/ 100 \mathrm{ml})$ under constant stirring for 15 minutes. Then disinfected tissues were washed with sterile distilled water 3 times.

For shoot differentiation, the basal medium of Murashige and Skoog (10) was modified 30 times by adding different concentrations of hormones (NAA, IBA, 2,4-D, IAA, Kinetin, BA), coconut water, casein hydrolisate, and adenine sulfate (table 1). Similarly, Gamborg B5 medium (6) was modified by adding different concentrations of NAA, IBA and 2,4-D; and Abo and Zettler's (AZ) medium (1) was modified by adding NAA, IBA, 2,4-D, BA, and adenine sulfate.

TABLE 1.-Differenl media tried for shoot differentiation (concentrations in mg/L)

\begin{tabular}{|c|c|c|c|c|c|c|c|c|c|}
\hline $\begin{array}{l}\text { Basal } \\
\text { media }\end{array}$ & NAA & IBA & 2,4-D & IAA & Kin & $\mathrm{BA}$ & $\begin{array}{l}\text { Coconut } \\
\text { water }\end{array}$ & $\begin{array}{c}\text { Casein } \\
\text { hydrolisate }\end{array}$ & $\begin{array}{l}\text { Adenine } \\
\text { sulfate }\end{array}$ \\
\hline MS-1 & 0.1 & - & - & - & - & - & - & - & - \\
\hline MS-2 & 1.0 & - & - & - & - & - & - & - & - \\
\hline MS-3 & 2.0 & $\overline{ }$ & - & - & - & $\longrightarrow$ & - & - & $\longrightarrow$ \\
\hline MS-4 & - & 0.1 & - & $\longrightarrow$ & - & - & - & - & - \\
\hline MS-5 & - & 1.0 & - & - & - & - & - & - & - \\
\hline MS-6 & - & 2.0 & - & - & - & - & - & - & - \\
\hline MS-7 & - & - & 0.1 & - & - & - & - & - & - \\
\hline MS-8 & - & - & 1.0 & - & - & - & - & - & - \\
\hline MS-9 & - & - & 2.0 & - & - & - & - & - & - \\
\hline MS-10 & - & 2.0 & 2.0 & - & - & - & - & - & - \\
\hline MS-II & 2.0 & 2.0 & - & - & - & - & - & - & - \\
\hline MS-12 & 2.0 & - & 2.0 & - & - & - & - & - & - \\
\hline B5-13 & 0.1 & - & - & - & - & - & - & - & - \\
\hline B5-14 & 1.0 & - & - & - & - & - & - & - & - \\
\hline B5-15 & 2.0 & - & - & - & - & - & - & - & - \\
\hline B5-16 & - & 0.1 & - & - & - & - & - & - & - \\
\hline B5-17 & - & 1.0 & - & - & - & - & - & - & - \\
\hline B5-18 & - & 2.0 & - & - & - & - & - & - & - \\
\hline B5-19 & - & - & 0.1 & - & - & - & - & - & - \\
\hline B5-20 & - & - & 1.0 & - & - & - & - & - & - \\
\hline B5-21 & - & - & 2.0 & - & - & - & - & - & - \\
\hline B5-22 & - & 2.0 & 2.0 & - & - & - & - & - & - \\
\hline B5-23 & 2.0 & 2.0 & - & - & - & - & - & - & - \\
\hline B5-24 & 2.0 & - & 2.0 & - & - & - & - & - & - \\
\hline AZ-25 & 0.1 & - & - & - & - & - & - & - & - \\
\hline AZ-26 & 1.0 & - & - & - & - & - & - & - & - \\
\hline AZ-27 & 2.0 & - & - & - & - & - & - & - & - \\
\hline$A Z-28$ & - & 0.1 & - & - & - & - & - & - & - \\
\hline$A Z-29$ & - & 1.0 & - & - & - & - & - & - & - \\
\hline AZ-30 & - & 2.0 & - & - & - & - & - & - & - \\
\hline AZ-31 & - & - & 0.1 & - & - & - & - & - & - \\
\hline$A Z-32$ & - & - & 1.0 & - & - & - & - & - & - \\
\hline AZ-33 & - & - & 2.0 & - & - & - & - & - & - \\
\hline AZ-34 & - & 2.0 & 2.0 & - & - & - & - & - & - \\
\hline$A Z-35$ & 2.0 & 2.0 & - & - & - & - & $\longrightarrow$ & - & - \\
\hline
\end{tabular}


TABLE 1. Continued

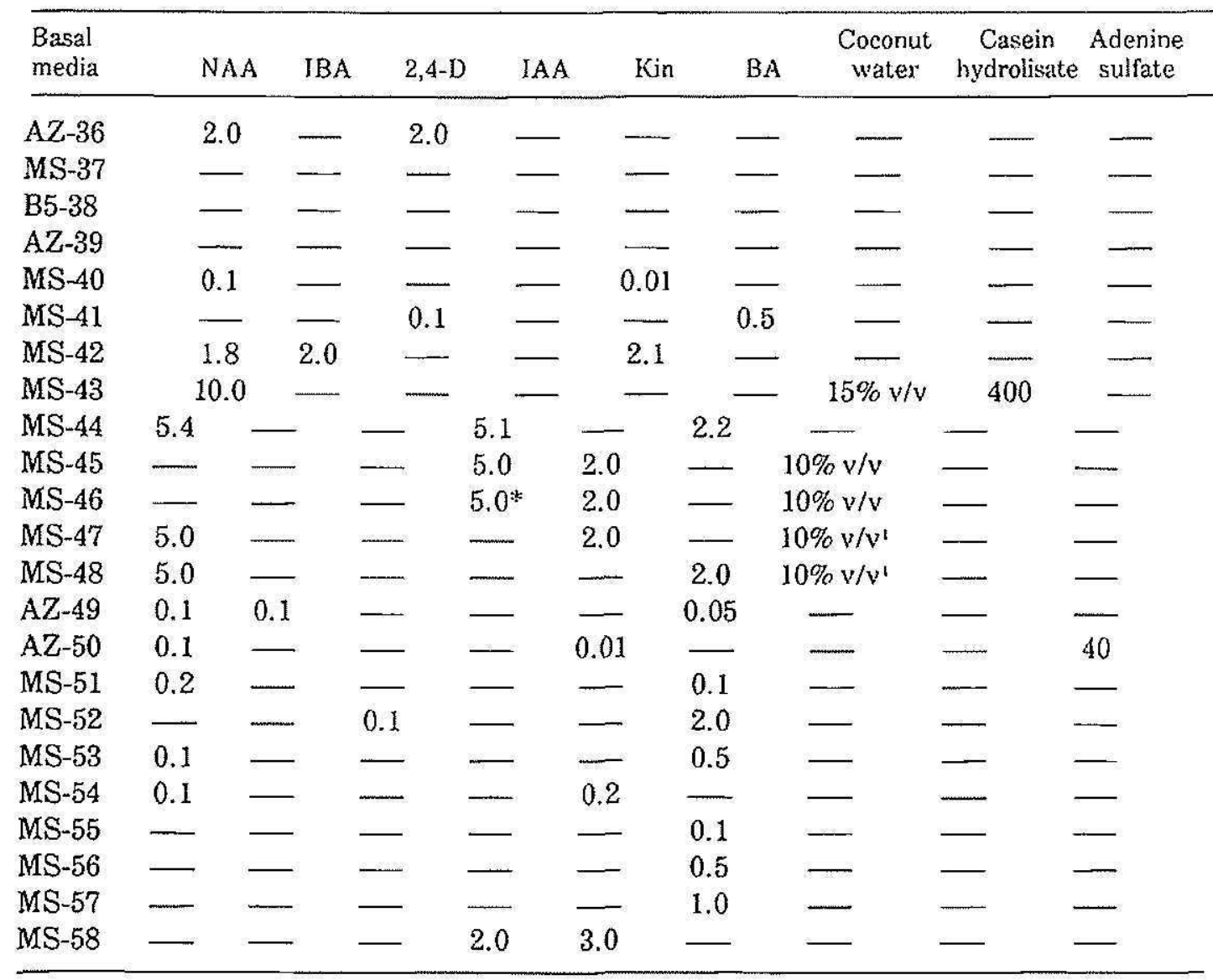

'Filter sterilized.

For the callus formation, the basal Murashige and Skoog's medium (10) was modified 4 times by adding different concentrations of hormones (BA, NAA, 2,4-D and kinetin); (table 2).

For the shoot proliferation, semi-solid and liquid media of MS and $\mathrm{AZ}$ were modified by adding different concentrations of hormones (NAA, IBA, 2,4-D, IAA, Kinetin, BA), coconut water, casein hydrolisate, and adenine sulfate (table 3 )

For the greenhouse hardening process, 1- to 2-month old pineapple plantlets derived from meristem culture were planted in a 72-hole plastic tray containing a mixture of Promix. The tray was placed in a greenhouse

TABLE 2.-Different hormone concentrations (mg/1), in MS basal medium, tested for callus formation

\begin{tabular}{ccccc}
\hline Basal media & BA & NAA & $2,4-\mathrm{D}$ & Kinetin \\
\hline MS & 10 & 4 & - & - \\
MS & 4 & 10 & - & - \\
MS & - & - & 0.02 & 12 \\
MS & - & - & 12 & 0.02 \\
\hline
\end{tabular}


J. Agric. Univ. P.R. vol. 73, No. 4, ocTOBER, 1989

TABLE 3.-Semi-solid and liquid medin tested for shoot proliferation (in mg/L)

\begin{tabular}{|c|c|c|c|c|c|c|c|c|c|}
\hline $\begin{array}{l}\text { Basal } \\
\text { media }\end{array}$ & IBA. & NAA & $2.4-\mathrm{D}$ & IAA & $\mathrm{BA}$ & Kin & $\begin{array}{l}\text { Adenine } \\
\text { sulfate }\end{array}$ & $\begin{array}{c}\text { Casein } \\
\text { hydrolisate }\end{array}$ & $\begin{array}{l}\text { Coconut } \\
\text { water }\end{array}$ \\
\hline MS & - & 10.0 & - & - & - & . & - & 400.0 & $15 \%$ \\
\hline MS & - & 5.4 & - & 5.1 & 2.2 & - & - & - & - \\
\hline MS & - & 0.2 & - & - & - & - & - & - & - \\
\hline $\mathrm{AZ}$ & - & 0.1 & - & - & - & 0.1 & 40.0 & - & $\ldots$ \\
\hline MS & - & 0.1 & - & - & - & 0.01 & 40.0 & - & - \\
\hline $\mathrm{AZ}$ & 0.1 & 0.1 & - & - & 0.05 & - & - & - & - \\
\hline MS & - & - & 0.1 & - & 0.5 & - & - & - & - \\
\hline MS & - & - & - & 2.0 & 一 & 3.0 & - & - & 一 \\
\hline MS & 2.0 & 1.8 & - & - & - & 2.1 & - & - & - \\
\hline
\end{tabular}

with misting facilities at $80 \%$ relative humidity, 75 to $85^{\circ} \mathrm{F}$ and low light intensity for 3 to 4 weeks. The plantlets with a strong root system were then transferred to a 5 -inch polyethylene bag containing Promix for another 3 to 4 weeks before field planting. Osmocote 18-6-20 (slow release fertilizer) was used to fertilize the plantlets every 3 months.

For reversion and somaclonal variability studies, Murashige and Skoog's basal medium $+0.1 \mathrm{mg} / 12,4-\mathrm{D}$ and $0.5 \mathrm{mg} / 1 \mathrm{BA}$ was used to propagate the spineless Red Spanish pineapple. Close observations were made on the following 4 types of variability and reversion: 1) reversion from spineless to spiny; 2) reversion from spiny to spineless; 3) spineless remaining spineless; 4) spiny remaining spiny in the laboratory and greenhouse during 3 - to 4 -month periods.

\section{RESULTS}

Callus induction and regeneration

Callus formation was observed when BA hormone was added to the basal medium of Murashige and Skoog (10), and incubated in the dark. The BA hormone played an important role in callus formation in the dark. No callus formation in the dark was observed in the culture medium without BA. The basal medium of MS $+10 \mathrm{mg} / \mathrm{L} \mathrm{BA}$ and $4 \mathrm{mg} / \mathrm{L} \mathrm{NAA}$ gave the best results on callus formation (fig. 1a and table 2).

The culture medium (MS $+4 \mathrm{mg} / \mathrm{L} \mathrm{NAA}$ ) gave the best results for plant regeneration. Calli of the Red Spanish pineapple were regenerated into green plantlets 2 to 3 weeks after incubation in diffuse light ( 2 to 3 foot candle), at $26^{\circ} \mathrm{C}$.

Shoot differentiation

The Murashige and Skoog's medium (10) with low concentration of 2,4-D (MS + $0.1 \mathrm{mg} / 2,4-\mathrm{D})$ and Abo El-Nil and Zettler (AZ) (1) with low concentration of NAA ( $\mathrm{AZ}+0.1 \mathrm{mg} / \mathrm{L} \mathrm{NAA}$ ) were the best combinations for shoot differentation (fig. 1b). Similarly, AZ medium with 2 $\mathrm{mg} / \mathrm{L} \mathrm{NAA}, \mathrm{AZ}+2 \mathrm{mg} / \mathrm{L} 2,4-\mathrm{D}$ or $\mathrm{MS}+0.1 \mathrm{mg} / \mathrm{L} 2,4-\mathrm{D}+0.5 \mathrm{mg} / \mathrm{L}$ 


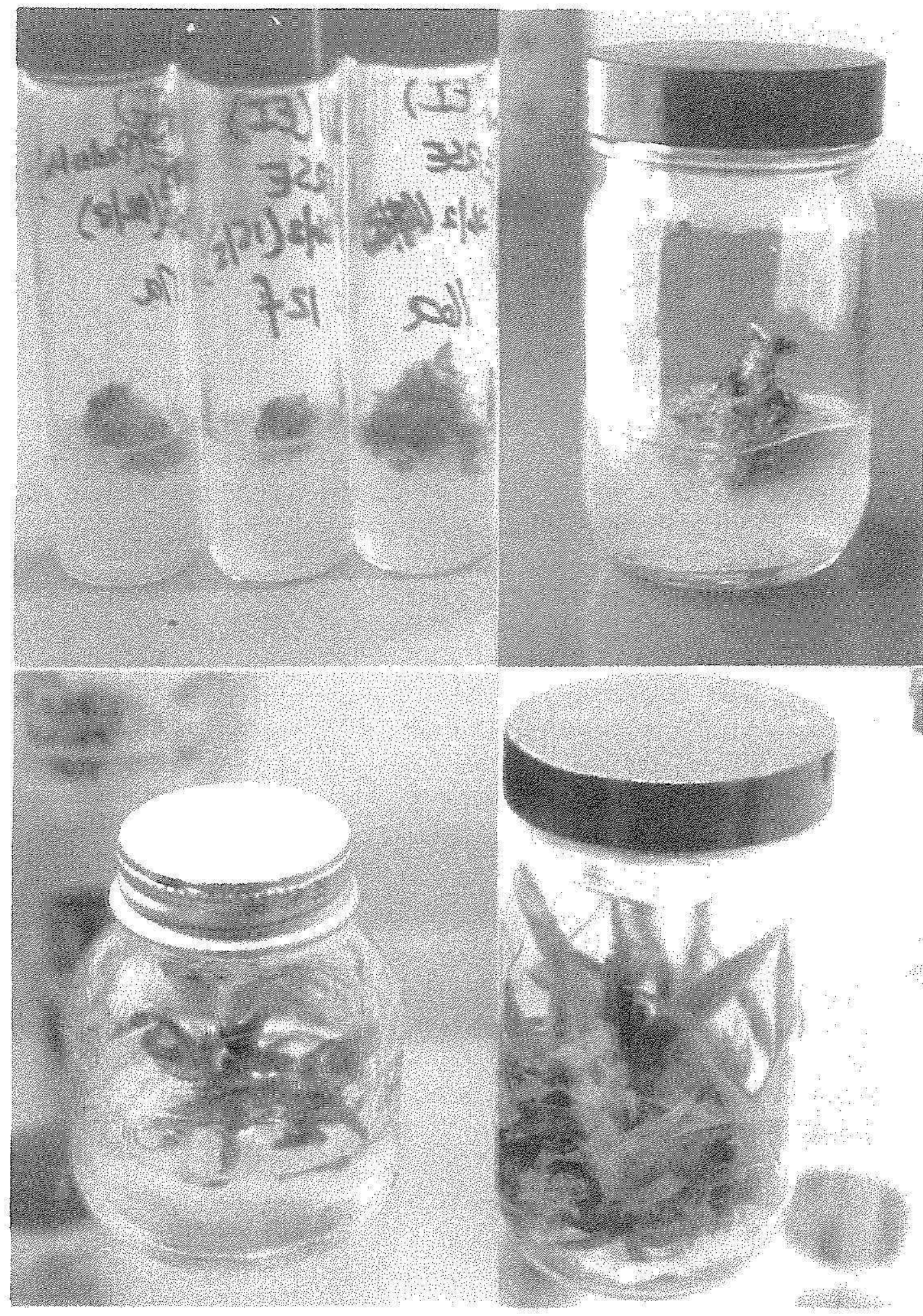

FIG. 1.-Growth of Red Spanish pineapple cultivar in the improved cultural media: (a) Callus formation in MS $+10 \mathrm{mg} / \mathrm{LBA}$ and $4 \mathrm{mg} / \mathrm{L} \mathrm{NAA}$, (b) Shoot differentiation in MS $+0.1 \mathrm{mg} / \mathrm{L}, 2,4-\mathrm{D}$, (c) Shoot proliferation in semi-solid MS basal medium $+0.1 \mathrm{mg} / \mathrm{L} \mathrm{2,4-D}$ $+0.5 \mathrm{mg} / \mathrm{L} \mathrm{BA}$, and (d) Shoot growth in solid medium of $\mathrm{MS}+5.2 \mathrm{mg} / \mathrm{L} \mathrm{IAA}+2.2 \mathrm{mg} / \mathrm{L}$ BA. 


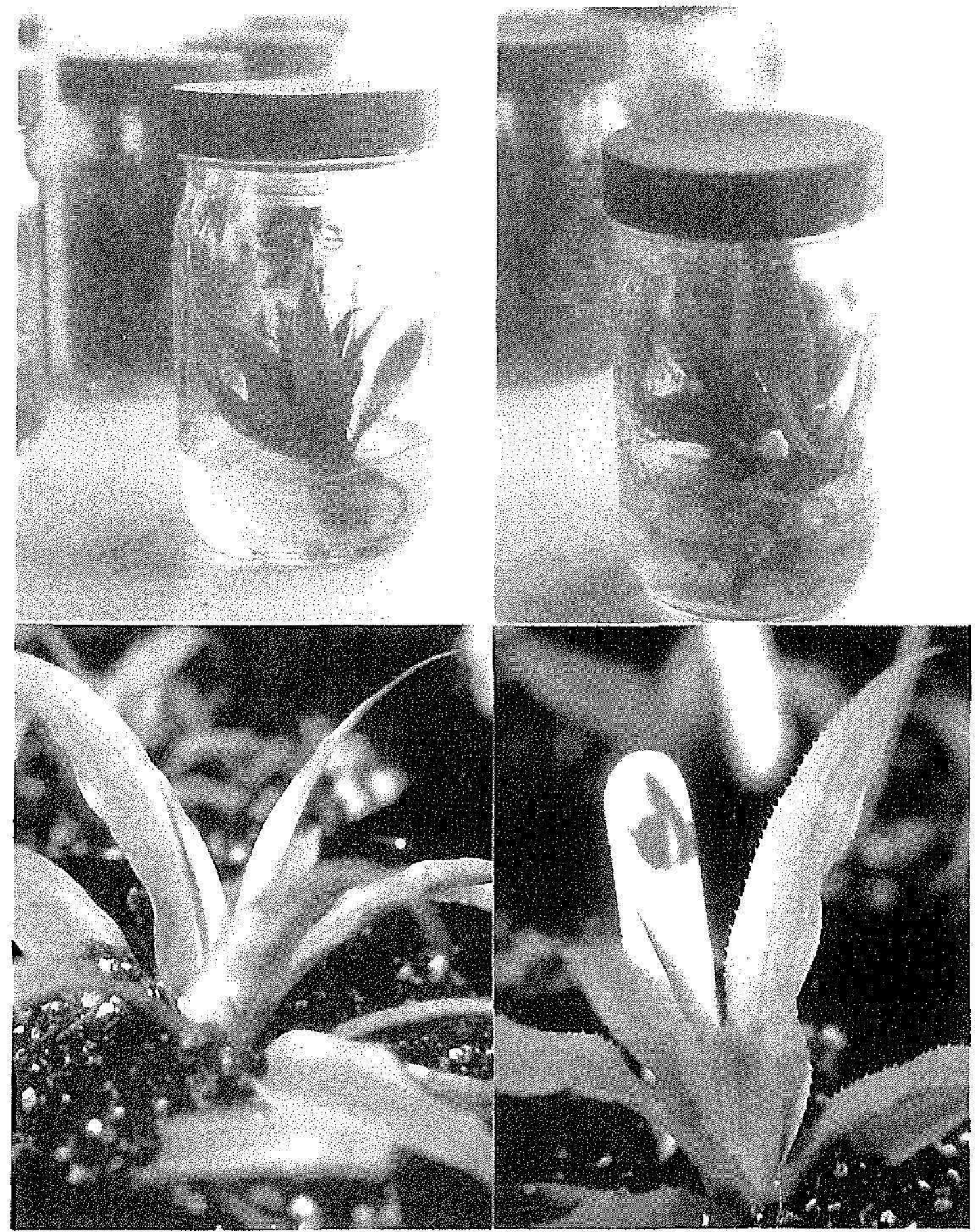

FrG. 2,-Reversion from spiny Red Spanish pineapple plantlets to smooth leaf (Spineless) in the laboratory ( $a$ and $b$ ) and in the greenhouse (c and d).

BA also permitted good shoot differentiation. The others, as mentioned in table 2, did not give as good shoot differentiation as the above-mentioned two culture media combinations. 
Shoot proliferation

of the 9 semi-solid and liquid media used for shoot proliferation (table 3 ), the MS basal medium + $0.1 \mathrm{mg} / \mathrm{L} 2,4-\mathrm{D}+0.5 \mathrm{mg} / \mathrm{L}$ BA gave the best results in shoot proliferation (fig. 1c). Similarly, the culture media (MS + 10mg/L NAA + coconut water $15 \%+400 \mathrm{mg} / \mathrm{L}$ casein hydrolisate and $\mathrm{MS}+5.4 \mathrm{mg} / \mathrm{L} \mathrm{NAA}+5.1 \mathrm{mg} / \mathrm{L} \mathrm{IAA}+2.2 \mathrm{mg} / \mathrm{L} \mathrm{BA}$ ) also gave good results (fig. $1 \mathrm{~d}$ ).

The results of this study revealed the possibility of selecting in vitro smooth leaf (spineless) pineapple plants and frequency of reversion. Some 40,000 plantlets of Red Spanish pinepapple were produced via meristem culture. Of these, approximately $50 \%$ were spineless. Some of these spineless plantlets reversed to spiny leaf (fig. 2). However, the percentage of reversion from spineless to spiny Red Spanish pineapple was $14.1 \%$, and that from spiny to spineless was $32.7 \%$. Of the 2,318 plantlets examined, $72.9 \%$ of the spiny Red Spanish pineapple remained spiny without reversion, and $85.8 \%$ of the spineless Red Spanish pineapple remained spineless with no reversion (table 4). One year after field planting, the spineless Red Spanish remained largely spineless and initiated flowering and fruit settings the same as the spiny ones (fig. 3).

\section{DISCUSSION}

The results obtained in this study agree with the findings of Fierro (5) that liquid medium with agitation accelerates the process of shoot proliferation. Similarly, the addition of hormones NAA at $10 \mathrm{mg} / \mathrm{L} \mathrm{(8)}$ and IAA at $5.1 \mathrm{mg} / \mathrm{L}$ and $\mathrm{BA}$ at $2.2 \mathrm{mg} / \mathrm{L}$ (9) also promotes proliferation and growth of the explants.

Variations in leaf color, density, spines, trichomes were observed on in vitro culture of pineapple (11). However, no efforts were made to induce and select them via hormones as useful agronomic characteristics for commercial propagation.

Collins and Kerns (4) in Hawaii investigated the inheritance of 3 leaf types: spiny, the typical form for cultivars in the "Spanish" group, spinytip, (smooth leaved), the form in the "Cayenne" group; and piping, the form of Monte Lirio and other smooth-leaf cultivars. They ascertained that spiny-tip and spiny leaves were phenotypic expression of a single pair of alleles, S and s, with spiny-tip (smooth leaved) dominant. Our experience in pineapple tissue culture indicates that the reversion from spiny to spineless (smooth leaved) was greater and the percentage of the spineless remaining spineless was higher. Therefore, somaclonal variability and reversion should not cause great concern in commercial production using tissue culture plantlets for propagation.

There are many advantages of in vitro culture of pineapple. It could be used either for obtaining useful variants as evidenced in this study or for accelerating propagation. It would theoretically be possible to obtain 
TABLE 4.-Wariability and reversion of spineless Red Spanish pineapple in Murashige and Skoog's basal medium with 0.1 mg/L $2,4 \cdot D$ and $0.5 \mathrm{mg} / L \mathrm{LA}$

\begin{tabular}{|c|c|c|c|c|c|}
\hline Variation/Reversion & $\begin{array}{l}\text { No. of plantlets } \\
\text { observed }\end{array}$ & $\begin{array}{l}\text { No. of plantlets } \\
\text { with reversion }\end{array}$ & $\begin{array}{l}\text { No. of plantlets } \\
\text { without reversion }\end{array}$ & Reversion & No Reversion \\
\hline $\begin{array}{l}\text { Reversion from spineless } \\
\text { to spine }\end{array}$ & 1,061 & 150 & - & $\begin{array}{c}\% \\
14.13\end{array}$ & $\%$ \\
\hline $\begin{array}{l}\text { Reversion from spine } \\
\text { to spineless }\end{array}$ & 2,318 & 758 & - & 32.70 & - \\
\hline $\begin{array}{l}\text { Spine remaining spine } \\
\text { (no reversion) }\end{array}$ & 2,318 & - & 1,560 & - & 72.96 \\
\hline $\begin{array}{l}\text { Spineless remaining spineless } \\
\text { (no reversion) }\end{array}$ & 1,061 & - & 911 & - & 85.86 \\
\hline
\end{tabular}




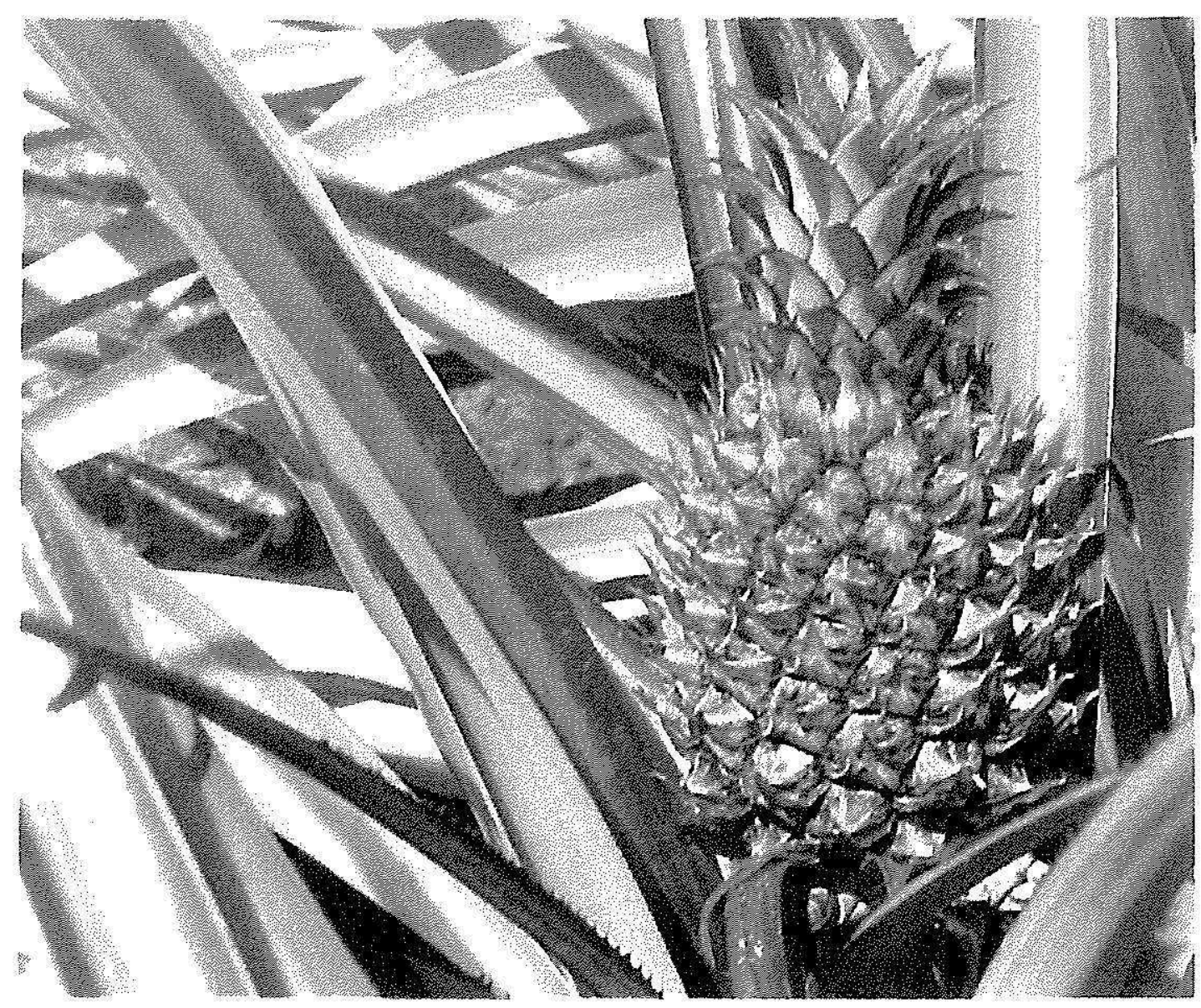

FIG. 3.-Normal fruit setting in field planting of Spineless Red Spanish pineapple via tissue culture.

one million plantlets from a single bud in 2 years. It may also be possible to create new genotypes for disease resistance through somaclonal selections.

\section{LITERATURE CITED}

1. Abo, El-Nil, M. F. and F. W. Zettler, 1976. Callus initiation and organ differentiation from shoot tip culture of Colocasia esculenta. Plant Sci. Lett. 6: 401-08.

2. Anónimo, 1984. Conjunto tecnológico para la produceión de piña en Puerto Rico. Esta. Esp. Agíc., Univ. P. R., Río Pjedras, P. R.

3. Castillo, O., 1978. Propagación masiva de piña Ananas comosus (L.) Merr., in vitro. Univ. P. R., Mayagüez Campus, M.S. Thesis.

4. Collins, J. L. and K. R. Kerns, 1946. Inheritance of three leaf types in the pineapple, J. Hered. 47: 124-28.

5. Fierro, C. A., 1986. Improved methods for multiplication of pineapple varieties. Proc. 1986 Tropical-Subtropical Agriculture Research, Jan. 16-17, 1986. Gainesville, Florida, pp. 32-8.

6. Gamborg, O. L., R. A. Miller and K. Ojima, 1968. Nutrient requirements of suspension of soybean root cells. Exp. Cell Res. 50: 151-58.

7. Leal, F. J. and J. Soule, 1977. "Maipure" a new spineless group of pineapple cultivars, Hont. Sci. 12 (4): 301-05. 
8. Mathews, H. V. and T. S. Rangan, 1981. Growth and regeneration of plantlets on callus cultures of pineapple. Sci. Hort. 14: 227-34.

9. —_ and - 1979. Multiple plantlets in lateral buds and leaf explants in in vitro culture of pineapple. Sci. Hort. 11 (4): 319-28.

10. Murashige, T. and F. Skoog, 1962. A revised medium for rapid growth and bioassays with tobacco tissue cultures. Physiol. Plant. 15: 473-97.

11. Py, C., J. J. Lacoeuithe, and C. Teisson, 1987. The pineapple cultivation and uses. Editions G. P. Maisonneure \& Larouse 10̄, rue Victor-Cousin, Paris.

12. Rangan, T. S., 1984. Pineapple. In: Handbook of Plant Cell Culture, Crops Species, McMillan Publishing Co., $373-382$ p.

13. Srinivasa Rao, N. K., R. Dore Swamy and E. K. Chackeo, 1981. Differentiation of plantlets in hybrid embryo callus of pineapple. Sci. Hort. 15: 235-238.

14. Traub, H. I'. and T. R. Robinson, 1938. (Pineapples). Improvement of subtropical fruits other than citrus. USDA Yearb., Sept. 1589: 35-42. 